\title{
PENGARUH ONLINE CONSUMER REVIEW DAN INFLUENCER TERHADAP KEPUTUSAN PEMBELIAN PRODUK DI MARKETPLACE SHOPEE
}

\author{
Ardiansyah Halim \\ Fakultas Bisnis dan Manajemen \\ Universitas Katolik Musi Charitas \\ e-mail : ardian160599@gmail \\ Maria Josephine Tyra \\ Fakultas Bisnis dan Manajemen \\ Universitas Katolik Musi Charitas \\ e-mail : tyra@ukmc.ac.id
}

\begin{abstract}
This study aims to prove the influence of online consumer reviews and influencers on product purchase decisions in the Shopee Marketplace. This type of research uses a quantitative approach. Palembang people aged 15 until 25 years who have made product purchase transactions in the Shopee Marketplace was used as sample of this research. The data source used is primary data, data collection in this study using survey techniques by distributing questionnaires. The method of measuring the questionnaire in this study uses a 5-point Likert scale. The data analysis technique used data quality test, classical assumption test, multiple linear regression analysis and hypothesis testing. From the test results, multiple linear regression analysis proves that the first hypothesis, that is, Online Consumer Review has a positive and significant effect on purchasing decisions in the Shopee Marketplace with significant value of 0.000 less than 0.05. As for the second hypothesis, namely Influencers have an effect on purchasing decisions in the Shopee Marketplace is rejected, with significant value of 0.221>0.05. The novelty element of this research is the importance of influencers to reveal truthful information related to products being sold to build consumer trust, which has not been stated by other researchers.
\end{abstract}

\begin{abstract}
ABSTRAK
Penelitian ini bertujuan untuk membutktikan adanya pengaruh online consumer review dan influencer terhadap keputusan pembelian produk di Marketplace Shopee. Jenis penelitian menggunakan pendekatan kuantitatif. Sampel yang digunakan adalah masyarakat Palembang dengan usia 15 s.d. 25 tahun yang sudah pernah melakukan transaksi pembelian produk di Marketplace Shopee. Sumber data yang digunkan adalah data primer, pengumpulan data dalam penelitian ini menggunakan teknik survei dengan menyebarkan kuisioner. Metode pengukuran kuesioner pada penelitian ini menggunakan skala likert 5 poin. Teknik analisis data menggunakan uji kualitas data, Uji asumsi klasik, Analisis regresi linier berganda dan uji hipotesis. Dari hasil uji analisis regresi linier berganda membuktikan untuk hipotesis pertama yaitu Online Consumer Review berpengaruh secara positif dan signifikan terhadap keputusan pembelian di Marketplace Shopee diterima. Dibutktikan dengan nilai signifikan 0,000 lebih kecil dari 0,05. Sedangkan untuk hipotesis kedua yaitu Influencer berpengaruh terhadap keputusan pembelian di Marketplace Shopee ditolak. Dibutktikan dengan nilai signifikan 0,221 >0,05. Unsur kebaruan dari penelitian ini adalah pentingnya influencer
\end{abstract}




\section{Buletin Ekonomi}

mengungkapkan informasi kebenaran terkait produk yang dijual untuk membangun kepercayaan konsumen, yang belum dinyatakan oleh peneliti lainnya.

Kata Kunci : Consumer review, Influencer, Keputusan pembelian.

\section{PENDAHULUAN}

Di era saat ini tak dapat dipungkiri bahwa internet menjadi sumber pendukung aktivitas disetiap golongan masyarakat. Internet menjadi sumber pendukung khususnya di bidang komunikasi. Saat ini informasi yang diperoleh dari satu orang ke orang lain dapat cepat diteima karena adanya internet. Media sosial dan e-commerce menjadi salah satu wujud nyata dampak dari internet. Adanya media soial sebagai tempat setiap orang dapat berkomunikasi dan berbagi informasi yang diperoleh tanpa batas tempat dan waktu. Hal ini juga dimanfaatkan para pebisinis yang sekarang sudah merambah kedunia online.

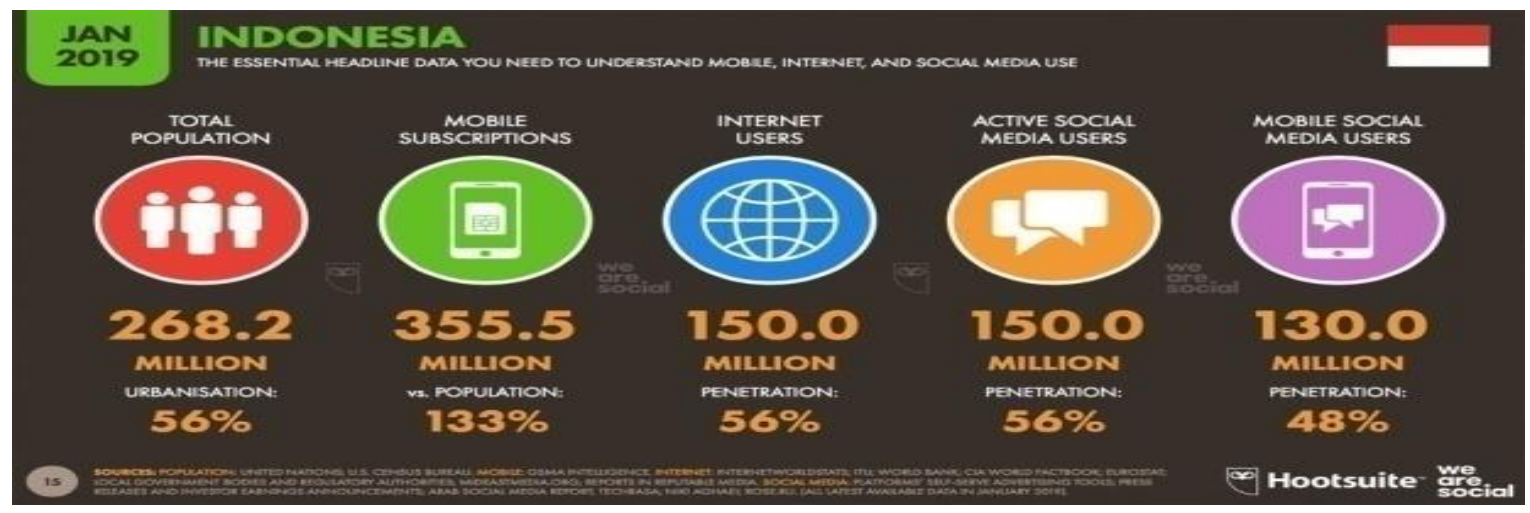

Sumber: Websindo.com., 2019

\section{Gambar 1. Data Pengguna Mobile, Internet, dan Media Sosial Januari 2019}

Di Indonesia sendiri intensitas pengguna internet cukup tinggi, dapat dilihat pada gambar disamping dengan jumlah penduduk mencapai 268,2 juta jiwa, 56\% atau sekitar 150 juta jiwa merupakan pengguna internet, dan 150 juta jiwa aktif di media sosial. Penggunaan Perangkat menjadi salah satu sarana dalam mengakses internet, sekitar $60 \%$ dari jumlah penduduk Indonesia menggunakan mobile phone khususnya smart phone untuk mengakses internet, ini menunjukkan bahwa separuh lebih penduduk di Indonesia merupakan pengguna internet yang mengakses internet melalui smartphone.

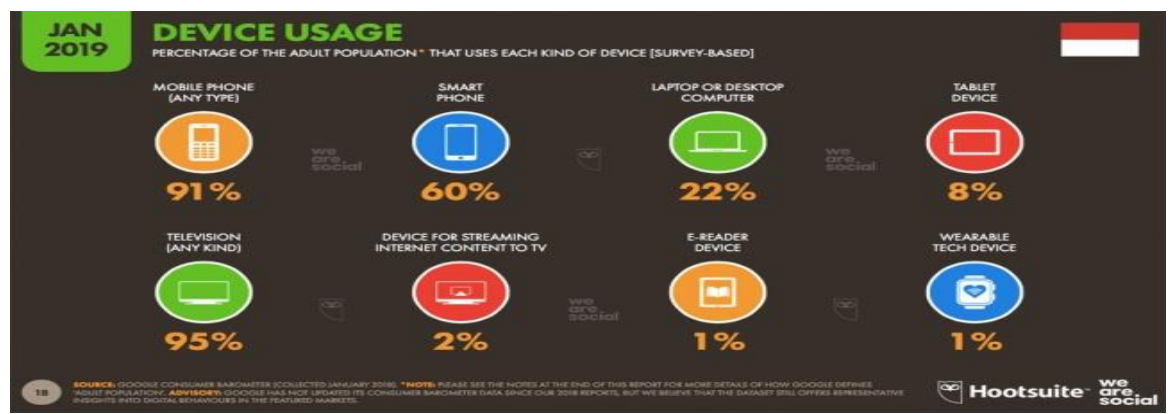

Sumber: Websindo.com., 2019

Gambar 2. Data Penggunaan Beragam Perangkat 
Selanjutnya pada Gambar 3 dapat dilihat bahwa dengan menggunakan data infografis dari Asosiasi Penyelenggara Jasa Internet Indonesia (APJII) menggambarkan penduduk Indonesia usia 15-19 tahun 91\% nya merupakan pengguna internet dan $9 \%$ nya bukan pengguna internet disusul diposisi kedua usia 20-24 tahun 88.5\% nya merupakan pengguna internet dan $11.5 \%$ nya bukan pengguna internet dari data terebut pengguna internet terbanyak berdasakan umur di dominasi oleh usia muda.

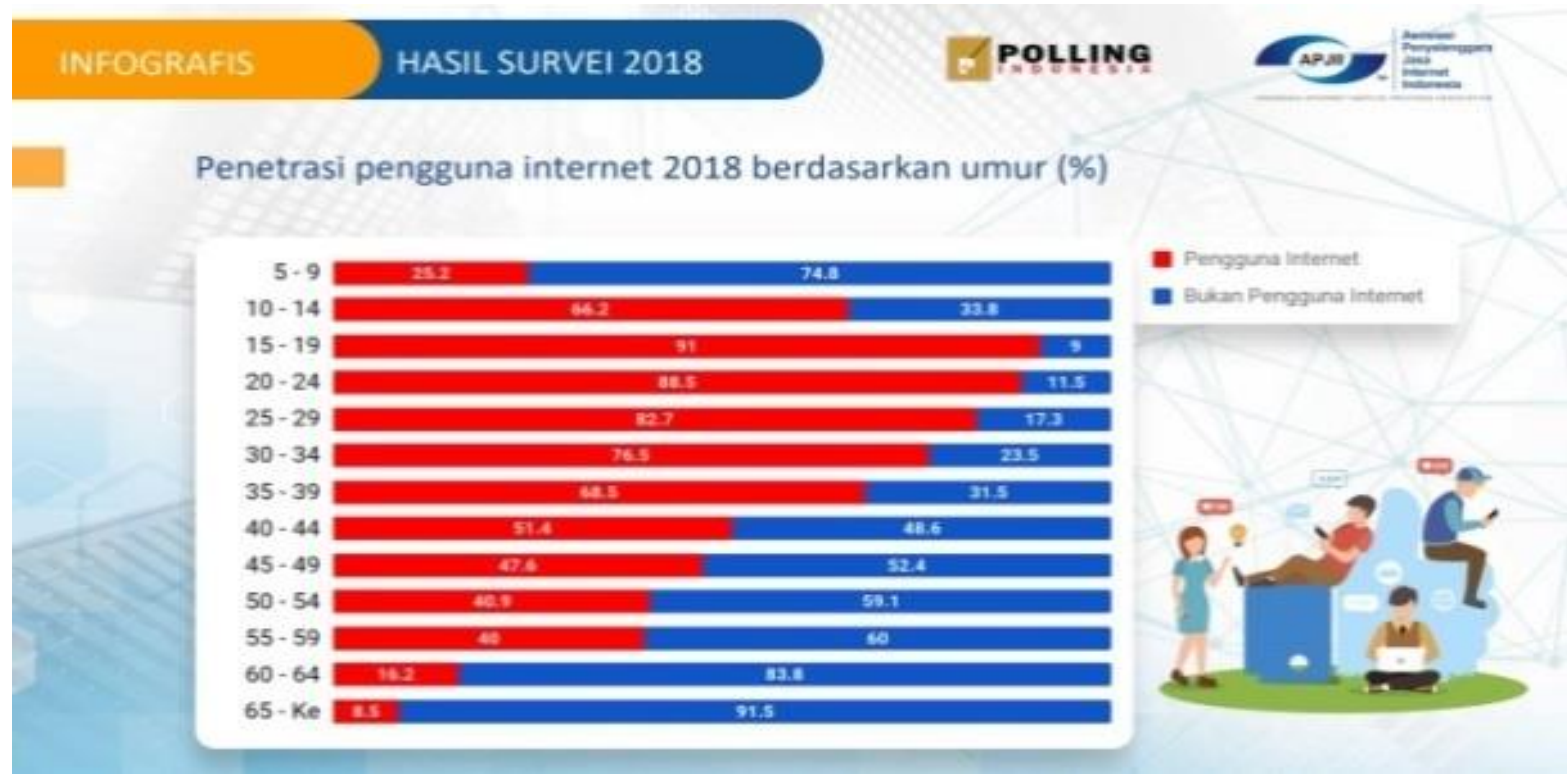

Sumber: APJII, 2018

\section{Gambar 3. Data Penetrasi Pengguna Internet Berdasarkan Usia}

Dari Badan Pusat Statistik (2018), di indonesia,khususnya Provinsi Sumatra Selatan, Kota Palembang diketahui menjadi kota dengan jumlah penduduk terbanyak sebesar 1.651.857 juta jiwa dan didominasi oleh kaum muda, pada posisi pertama dengan rentang usia 20-24 tahun sebesar 150.064 ribu jiwa dan posisi kedua dengan rentang usia 15-19 sebesar 150.839 ribu jiwa.

Tabel 1. Data Jumlah Penduduk Sumatera Selatan 2018

\begin{tabular}{|lrrr|}
\hline & \multicolumn{4}{c|}{2018} \\
Kelompok Umur & Jumlah Penduduk Menurut Kelompok Umur (Jiwa) \\
& Laki-laki & Perempuan & Jumlah \\
\hline $0-4$ & 73665 & 69796 & 143461 \\
\hline $5-9$ & 74200 & 69889 & 144089 \\
\hline $10-14$ & 70480 & 65733 & 136213 \\
\hline $15-19$ & 74430 & 75634 & 150064 \\
\hline $20-24$ & 76151 & 74683 & 150839 \\
\hline $25-29$ & 71340 & 68655 & 139995 \\
$30-34$ & 67730 & 65496 & 133226 \\
\hline $35-39$ & 63084 & 64841 & 127925 \\
\hline $40-44$ & 59527 & 60241 & 119768 \\
\hline $45-49$ & 51690 & 53163 & 104853 \\
\hline $50-54$ & 45555 & 47307 & 92862 \\
\hline $55-59$ & 38652 & 38935 & 77587 \\
\hline $60-64$ & 25431 & 25228 & 50659 \\
\hline $65-69$ & 16034 & 16722 & 32756 \\
\hline $70-74$ & 8836 & 11111 & 19947 \\
\hline $75+$ & 7281 & 11963 & 19244 \\
\hline Jumlah & 824086 & 819402 & 1643488 \\
& & & \\
\hline
\end{tabular}

\begin{tabular}{|c|c|c|c|c|}
\hline \multirow{2}{*}{ Kabupaten/Kota } & \multicolumn{4}{|c|}{ JumlahPenduduk } \\
\hline & 2015 & 2016 & 2017 & 2018 \\
\hline Ogan Komering Ulu & 349787 & 354488 & 359092 & 364260 \\
\hline Ogan Komering llir & 787513 & 798482 & 809203 & 821528 \\
\hline Muara Enim & 600398 & 609607 & 618762 & 628661 \\
\hline Lahat & 393235 & 397424 & 401494 & 405605 \\
\hline Musi Rawas & 384333 & 389239 & 394384 & 4002 \\
\hline Musi Banyuasin & 611506 & 620738 & 629791 & 6400 \\
\hline Banyuasin & $\mathbf{8 1 1 5 0 1}$ & 822575 & $\mathbf{8 3 3 6 2 5}$ & 846269 \\
\hline Ogan Komering Ulu Selatan & 344074 & 348574 & 352926 & 358510 \\
\hline Ogan Komering Ulu Timur & 649394 & 656568 & 663481 & 670653 \\
\hline Ogan llir & 409171 & 414504 & 419773 & 424774 \\
\hline Empat Lawang & 238118 & 241336 & 244312 & 247544 \\
\hline Pali & 179529 & 182219 & 184671 & 187554 \\
\hline Musi Rawas Utara & 182828 & 185315 & 187635 & 1902 \\
\hline Pallen & 1580517 & 16020711 & 1623 & 1651 \\
\hline Prabumulih & 177078 & 179563 & 182128 & 185895 \\
\hline PagarAlam & 133862 & 135328 & 136605 & 13 \\
\hline Lubuk Linggau & 219471 & 222870 & 226002 & 22988 \\
\hline Sumatera Selatan & 052315 & 81609018 & 82669838 & $839148 x$ \\
\hline
\end{tabular}

Sumber: Badan Pusat Statistik, 
2018.

Banyak nya jumlah pengguna internet yang ada menunjukkan bahwa internet sudah menjadi salah satu kebutuhan yang diperlukan pada zaman ini, banyaknya aktivitas yang dilakukan sekarang sangat berkaitan erat dengan internet, termasuk dalam hal belajar, bekerja maupun dalam proses pemenuhan kebtuhan hidup termasuk seperti para pebisnis yang sekarang ini sudah merambah ke dunia online. Direktur Pemberdayaan Informatika, Direktorat Jenderal Aplikasi Informatika Kementerian Kominfo, Septriana Tangkary menyatakan pertumbuhan nilai perdagangan elektronik (e-commerce) di Indonesia mencapai 78 persen, tertinggi di dunia (https://kominfo.go.id). Munculnya $e$-commerce menyebabkan banyaknya pilihan produk yang menjadi pertimbangan konsumen, hal ini menjadi peluang untuk menciptakan e-marketplace untuk mempertemukan penjual maupun reseller dan pembeli pada satu tempat. Marketplace adalah pasar virtual dimana penjual dan pembeli bertemu dan melakukan berbagai jenis transaksi. (http://teknonisme.com). Di indonesia sendiri 3 pemain besar e-commerce berbasis marketplace saat ini yaitu Tokopedia, Shopee, dan Bukalapak (https://iprice.co.id) Tokopedia dan bukalapak adalah marketplace yang berasal dari indonesia, sedangkan Shopee berasal dari Singapura. Shopee adalah marketplace dengan model bisnis Customer to customer (C2C) yaitu model bisnis di mana konsumen dari sebuah marketplace menjual produk ke sesama konsumen lainnya. .

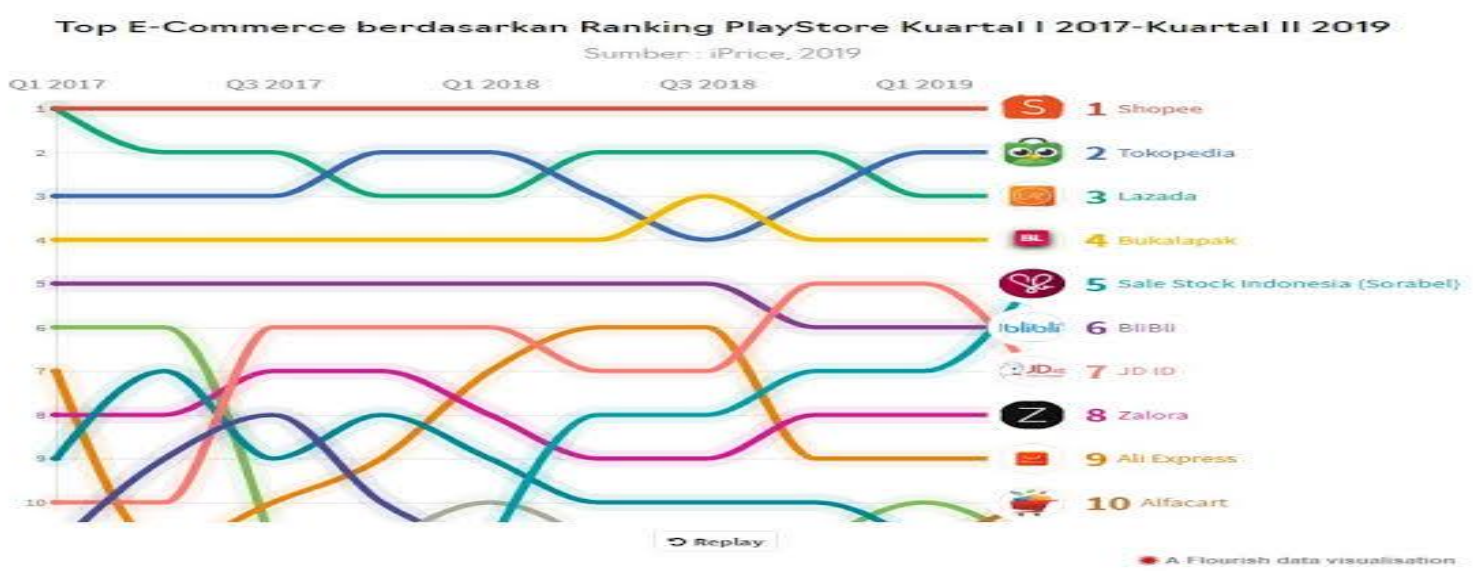

Sumber: Https://Iprice.Co.Id/Insights/Mapofecommerce.

Gambar 4. Top E-Commerce Berdasarkan Rangking Playstore

Dari Gambar 4, diketahui Shopee menduduki peringkat pertama sebagai aplikasi marketplace yang paling banyak diunduh di Playstore. Disusul Tokopedia di peringkat kedua dan Lazada di peringkat ketiga. Shopee mencatat Gross Merchandise Value (GMV) atau keseluruhan volume transaksi di Indonesia pada kuartal pertama 2019 menyentuh angka US\$1,4 miliar atau sekitar Rp20,1 triliun. Angka ini menyumbang dua pertiga dari total transaksi Shopee di Asia Tenggara dan Taiwan. (https://cnnindonesia.com). banyaknya jumlah transaksi menunjukkan bahwa Saat ini Shopee menjadi marketplace yang cukup digemari konsumen Indonesia dalam mencari produk yang mereka butuhkan Sekarang dalam memenuhi kebutuhan hidup khususnya dalam hal pembelian produk berupa barang dapat dilakukan dengan cepat karena adanya internet. Disatu sisi konsumen dapat lebih 
mudah menenmukan barang yang dibutuhkan ,namun disisi yang lain masih ada kekhawatiran konsumen dalam memutuskan untuk membeli produk, salah satunya karena barang yang dipesan tidak dapat dilihat dan dipegang secara langsung melainkan hanya berupa gambar dan informasi tertulis berisi keterangan produk. Hal tersebut masih menimbulkan keraguan bagi konsumen dalam keputusannya untuk membeli. Keraguan ini membuat konsumen mencari informasi lebih untuk memastikan bahwa barang yang ingin dibeli sesuai yang diharapkan. Rekomendasi serta ulasan dari konsumen yang sudah menggunakan produk menjadi salah satu informasi yang diperlukan untuk menilai suatu produk sebelum akhirnya memutuskan untuk membeli produk tersebut

Menurut Kotler \& Keller (2009) dalam bukunya yang berjudul Managemen Pemasaran memaparkan bahwa Word of Mouth Communication (WOM) atau komunikasi dari mulut ke mulut merupakan proses komunikasi yang berupa pemberian rekomendasi baik secara individu maupun kelompok terhadap suatu produk atau jasa yang bertujuan untuk memberikan informasi secara personal. Menurut pendapat Kotler \& Keller (2009), saluran komunikasi ini dapat menjadi metode promosi yang efektif karena pada umumnya disampaikan dari konsumen oleh konsumen dan untuk konsumen, sehingga pelanggan yang puas dapat menjadi media iklan bagi perusahaan. Menurut Konstantopoulou, Anastasia et al.(2018) WOM memainkan peran penting di pasar karena membantu konsumen untuk membentuk sikap dan perilaku mereka. Dengan kecanggihan teknologi saat ini, WOM bisa dijalankan melalui platform online yang diakses banyak orang Seperti media sosial, website, marketplace atau sekarang yang kita kenal dengan E-WOM (Electronic Word of Mouth). Online consumer review salah satu bentuk Ewom yang bersifat informational oriented, Online Consumer Reviews dapat diartikan sebagai umpan balik dan rekomendasi dari konsumen yang berpengalaman atas produk dan jasa tertentu dan dapat menimbulkan minat beli pada konsumen potensial (Khammash, 2008).

Shopee sebagai marketplace menyediakan fitur online consumer review sebagai sarana calon konsumen untuk mendapatkan informasi dari ulasan konsumen yang sudah mengunakan produk tersebut. Menurut econsultancy.com, pada umumnya sekitar 61 persen pembeli akan membaca ulasan online sebelum membuat keputusan pembelian atau pemesanan suatu produk. Sedangkan di Indonesia, ada sekitar 95 persen pembeli mengkaji suatu produk atau layanan melalui ponsel. Kehadiran fitur online review menjadi informasi tambahan yang dapat memengaruhi asumsi dan keputusan konsumen terkait penjual atau produk yang bersangkutan.(Agustina, Lydia et. al., 2018).

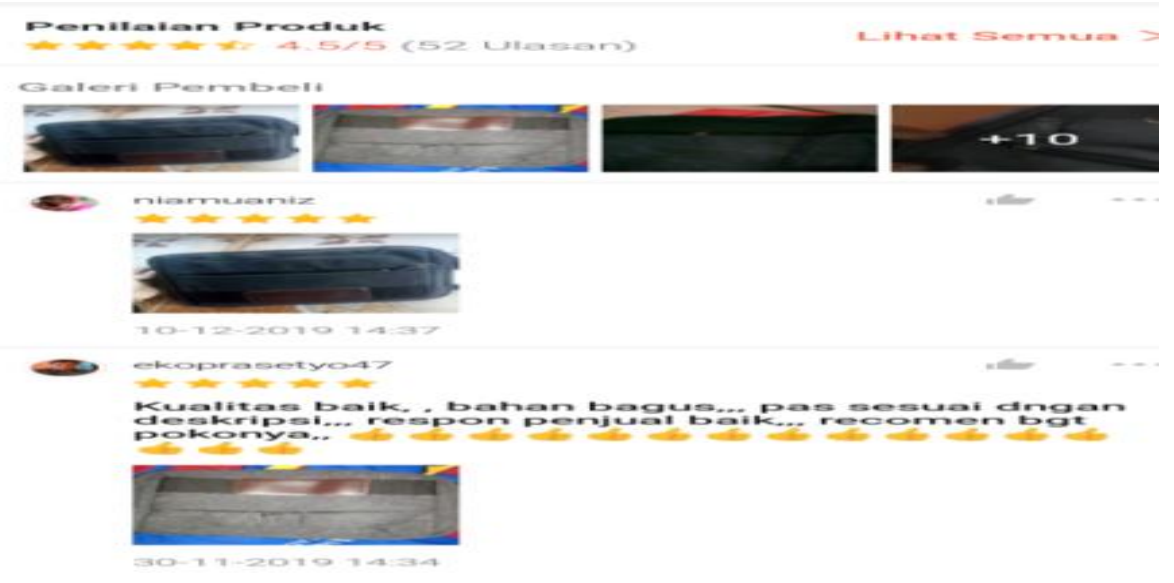

Sumber: Aplikasi Shopee 
Gambar 5. Fiture Online Consumer Review Shopee

Dari hasil penelitian terdahulu yang dilakukan oleh Kamila, Korina Tasya et al.(2018)dalam penelitiannya yang berjudul Pengaruh Online Consumer Review Terhadap Keputusan Pembelian menyimpulkan bahwa Online Consumer Review memiliki pengaruh signifikan terhadap variabel Keputusan Pembelian. Di zaman yang serba online ini, infomasi dapat diperoleh dengan mudah dan cepat, Kotler dan Keller (2016) mendefinisikan media sosial sebagai alat atau cara yang dilakukan oleh konsumen untuk membagikan informasi berupa teks, gambar, audio, dan video kepada orang lain dan perusahaan atau sebaliknya.

Infografis dari Websindo.com (2019) pada Gambar 6, di bawah ini menunjukkan tentang perkembangan pengguna media sosial. Total pengguna mencapai 150 juta pengguna, ini berarti mayoritas penggunaan internet untuk bersosialisasi melalui media sosial. Jumlah pengguna media sosial ini mencapai $56 \%$ dari jumlah total penduduk Indonesia, dengan pengguna berbasis mobilenya mencapai 130 juta.

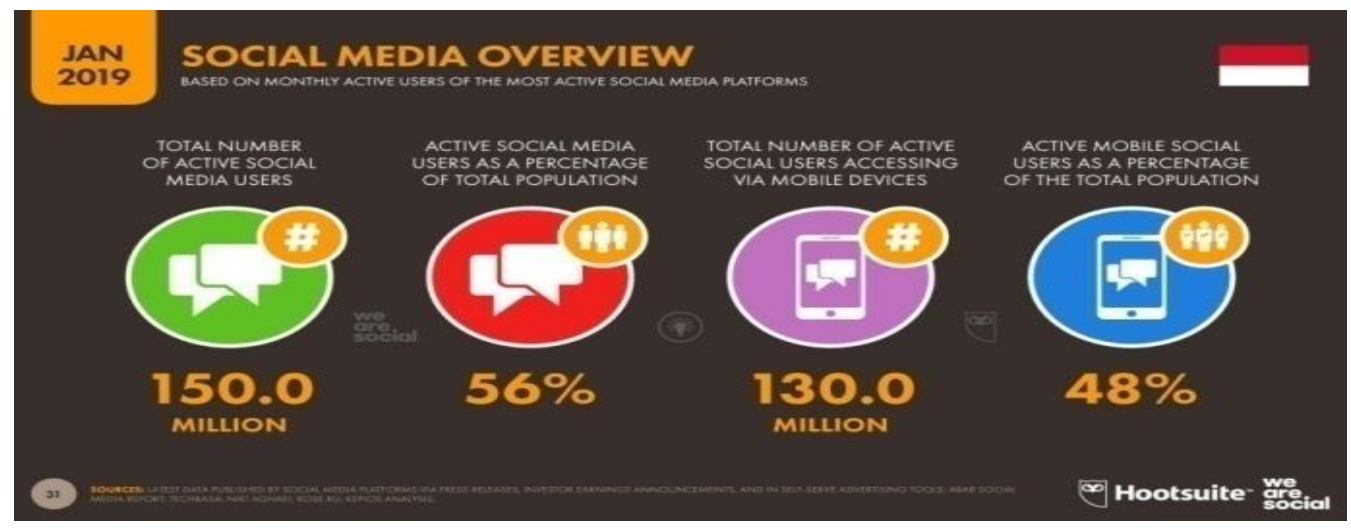

Sumber: Websindo.com, 2019

Gambar 6. Pengguna Sosial Media

Tingginya penggunaan media sosial sebagai sarana komunikasi dan bersosialisasi menjadi tempat untuk konsumen mencari dan berbagi informasi, termasuk dalam proses keputusan pembelian produk. Menurut Konstantopoulou, Anastasia et al.(2018) Media sosial telah membuka jalur untuk e-WOM dan munculnya influencer media sosial sekarang memiliki akses ke jutaan pengikut, dan berganti menjadi pelanggan potensial. Dalam penelitian yang dilakukan oleh Booth, Norman and Julie Ann Matic (2011) mengatakan bahwa Di dunia media sosial, praktisi (pelaku usaha) mengubah cara berkomunikasi dengan target mereka. walau dasar-dasar hubungan masyarakat pada dasarnya sama dengan hubungan media sosial, penambahan saluran pemasaran baru ini memungkinkan para praktisi untuk terlibat dengan influencer satu lawan satu. Influencer merupakan seseorang yang perkataannya dapat mempengaruhi orang lain. Seorang influencer tidak hanya harus selebrity, tetapi orang biasa pun dapat dikatakan sebagai influencer jika orang tersebut memiliki pengikut yang banyak dan perkataannya dapat mempengaruhi orang lain (Sugiharto et al., 2018).

Influencer yang kompeten adalah mereka yang memiliki kredibilitas tinggi sebagai sumber, Ketika konsumen mempercayai influencer, mereka menerima rekomendasi yang dapat mengubah keputusan pembelian mereka. Bagi perusahaan untuk membangun hubungan yang baik dengan basis pelanggan mereka, penting mereka bekerja dengan influencer yang dipercaya oleh sebagian besar audiens target (Konstantopoulou, Anastasia et al., 2018). 
Berdasarkan latar belakang di atas, maka rumusan masalah pada penelitian ini adalah:

1. Apakah Online Consumer Review mempengaruhi keputusan pembelian produk di Marketplace Shopee?

2. Apakah Influencer mempengaruhi keputusan pembelian produk di Marketplace Shopee ?

\section{Grand Theory}

Teori TAM (Technology Acceptance Model)

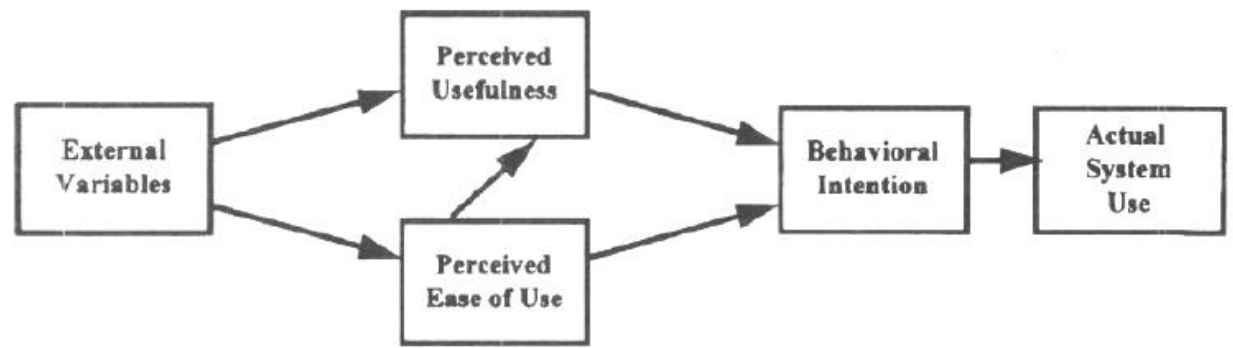

\section{Gambar 7. Teori TAM}

Teori TAM (Venkatesh and Davis, 2000) menunjukkan bahwa keinginan perilaku individual untuk menggunakan suatu sistem ditentukan oleh dua keyakinan, yaitu: (a) Manfaat yang dirasakan (perceived usefulness), yang didefinisikan dimana seseorang merasa yakin bahwa dengan menggunakan system tersebut akan meningkatkan kinerja pekerjaannya. Pengukuran manfaat tersebut berdasarkan frekuensi penggunaan dan keragaman aplikasi yang dijalankan. Seseorang akan menggunakan teknologi informasi jika mengetahui manfaat positif atas penggunaan teknologi informasi tersebut (Thompson, 1991), dan (b) Kemudahan penggunaan (perceived ease of use), yang didefinisikan dimana seseorang merasa yakin dengan menggunakan sistem tersebut tidak memerlukan upaya apapun (free of effort).

Model ini menggambarkan bahwa pengguna sistem infornasi akan dipengaruhi oleh variabel manfaat (usefullness) dan variabel kemudahan pemakaian (ease of use), yang kemudian mempengaruhi kecenderungan niat penggunaaan atau Intention to use yang dipengaruhi oleh sikap terhadap penggunaan sebuah sistem informasi atau aplikasi, serta efek langsung dan tidak langsung dari manfaat yang dirasakan dan persepsi kemudahan pengguna.

Teori Kredibilitas Sumber

Teori kredibilitas sumber (source of credibility theory) yang dikemukakan oleh Hovland, Janis, dan Kelly (1953) dalam bukunya Communicationand Persuasion. menyatakan bahwa orang akan lebih mungkin dipersuasi ketika komunikator atau orang yang menyampaikan pesan komunikasi menunjukkan dirinya sebagai orang yang kredibel atau dengan kata lain sumber komunikasi yang memiliki kredibilitas tinggi akan lebih efektif dalam mengubah opini seseorang dibandingkan dengan sumber komunikasi yang sumber kredibiltasnya rendah. 


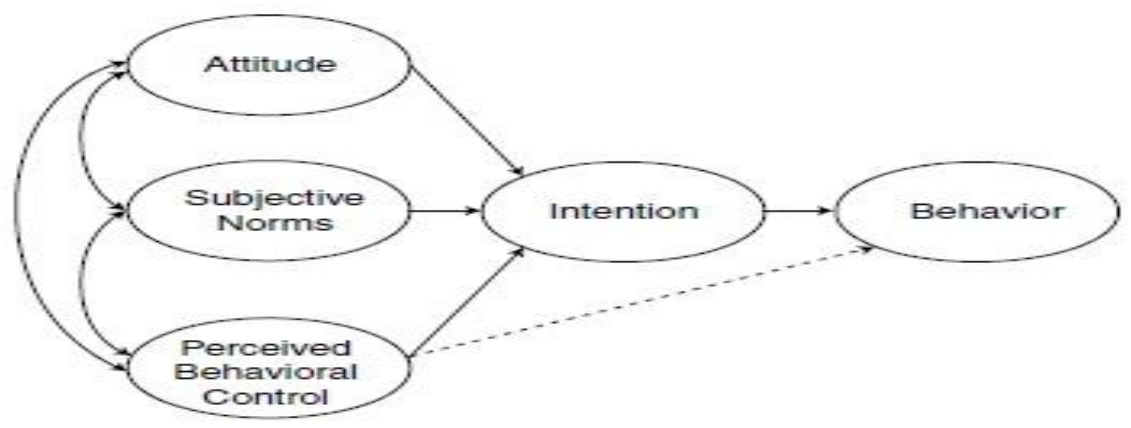

Gambar 8. Theory of Planned Behavior

Theory Of Planned Behavior (TPB) yang dikemukakan oleh Ajzen (1985) merupakan pengembangan dari Theory of Reasoned Action (TRA) oleh Fishbein dan Ajzen (1975) yang ditujukan untuk memprediksi perilaku individu secara lebih spesifik.

Online Consumer Review

Sutanto dan Aprianingsih (2016) mendefinisikan online consumer review sebagai salah satu bentuk dari electronic word of mouth dan dapat dikatakan sebagai komunikasi permasaran yang baru dan dapat mempengaruhi serta memegang peran dalam proses keputusan pembelian. Dimensi untuk mengukur online consumer review adalah:

Perceived Usefulness (Manfaat yang dirasakan)

Kegunaan dari Online Consumer Review adalah sejauh mana ulasan secara online akan memudahkan proses pengambilan keputusan pembelian konsumen. Kegunaan Online Consumer Review menjadi aspek bagi pengguna untuk mengukur sebuah online consumer review. Dengan banyaknya jumlah informasi, hanya komentar dan opini yang bernilai yang akan mempengaruhi pembuatan keputusan konsumen (Tasya kamila,korina et al., 2018.

\section{Influencer}

Influencer merupakan seseorang yang perkataannya dapat mempengaruhi orang lain. Seorang influencer tidak hanya harus selebrity, tetapi orang biasa pun dapat dikatakan sebagai influencer jika orang tersebut memiliki pengikut yang banyak dan perkataannya dapat mempengaruhi orang lain. (Shiya Azi Sugiharto et al., 2018). Dimensi untuk mengukur influencer dalam penelitian ini yaitu:

1. Kredibilitas

a. Kredibilitas menurut sumber yang dikemukakan oleh Hovland, Janis, dan Kelly (1953) dalam bukunya Communicationand Persuasion menyatakan bahwa orang akan lebih mungkin dipersuasi ketika komunikator atau orang yang menyampaikan pesan komunikasi menunjukkan dirinya sebagai orang yang kredibel atau dengan kata lain sumber komunikasi yang memiliki kredibilitas tinggi akan lebih efektif dalam mengubah opini seseorang dibandingkan dengan sumber komunikasi yang sumber kredibiltasnya rendah. .

2. Daya tarik (Attractiveness)

Dengan penampilan fisik yang baik atau karakter non fisik yang menarik dapat menunjang iklan dan dapat menimbulkan minat audience untuk menyimak iklan. Indikator pengukuran daya tarik adalah sebagai berikut: 
a. Similarity merupakan persepsi khalayak berkenaan dengan kesamaan yang dimiliki dengan endorser, kemiripan ini dapat berupa karakteristik demografis, gaya hidup, kepribadian, masalah yang dihadapi sebagaimana yang ditampilkan pada iklan, dan sebagainya.

b. Familiarity adalah suatu takar popularitas seorang influencer di mata audiens mereka..

c. Likability adalah kesukaan audiens terhadap narasumber karena penampilan fisik yang menarik,perilaku yang baik, atau karakter personal lainnya.

3. Source power

Source power adalah karisma yang dipancarkan oleh narasumber sehingga dapat mempengaruhi pemikiran, sikap, atau tingkah laku konsumen karena pernyataan atau pesan endorser tersebut.

Keputusan pembelian

Stanton et, al. (2000) menyatakan bahwa keputusan membeli merupakan proses dalam pembelian nyata setelah melalui berbagai tahap sebelumnya. Setelah melakukan evaluasi atas sejumlah alternatif maka konsumen dapat memutuskan apakah produk akan dibeli atau tidak (Peter dan Olson,1999). .Menurut Swasta dan Handoko (2008) sebuah keputusan untuk membeli suatu produk yang dipilih konsumen sebenarnya merupakan kumpulan dari sejumlah keputusan indikator pengukuran . Dalam penelitian ini, aspek-aspek yang digunakan untuk mengukur yaitu transaksional, referensial, preferensial, dan eksploratif (Ferdinand, 2002).

Hipotesis menurut Sugiyono (2012) merupakan jawaban sementara terhadap rumusan masalah penelitian, di mana rumusan masalah telah dinyatakan dalam bentuk kalimat pertanyaan. Berdasarakan tinjaun teori, penelitian terdahulu dan yang sudah dijelaskan maka perumusan hipotesis dalam penelitian ini adalah sebagai berikut:

H1 : Online consumer review berpengaruh positif dan signifikan terhadap keputusan pembelian produk di Marketplace Shoppe

$\mathrm{H} 2$ : Influencer berpengaruh positif dan signifikan terhadap keputusan pembelian produk di Marketplace Shoppe

\section{METODE}

Penelitian ini menggunakan pendekatan kuantitatif Menurut Sugiyono (2015) mendefinisikan metode penelitian kuatitatif sebagai metode penelitian yang berlandaskan pada filsafat positifme, digunakan untuk meneliti pada populasi atau sampel tertentu, pengumpulan data menggunakan instrumen penelitian, analisis data bersifat kuantitatif atau statisik, dengan tujuan untuk menguji hipotesis yang telah ditetapkan.

Populasi adalah wilayah generalisasi yang terdiri atas objek atau subjek yang mempunyai kualitas dan karakteristik tertentu yang ditetapkan oleh peneliti untuk dipelajari dan kemudian ditarik kesimpulannya (Sugiyono, 2012) Populasi dalam penelitian ini adalah masyarakat kota Palembang yang pernah melakukan transaksi di marketplace Shopee. Sedangkan sampel adalah bagian dari jumlah karakteristik yang dimiliki oleh populasi tersebut. Jika populasi besar, dan tidak mungkin mempelajari semua yang ada pada populasi, maka peneliti dapat menggunakan sampel yang diambil dari populasi tersebut (Sugiyono, 2012). Sampel yang digunakan dalam penelitian ini adalah masyarakat kota Palembang yang pernah melakukan transaksi di Marketplace Shopee dengan minimal 2 kali dalam 1 bulan. Jumlah sampel yang ditetapkan untuk populasi yang besar dan jumlahnya tidak diketahui, digunakan rumus menurut Rao Purba (2006) dalam Kharis (2011) sebagai berikut : 
Keterangan :

$$
n=\frac{Z^{2}}{4(m o e)^{2}}
$$

$\mathrm{n}=$ Jumlah sampel

$\mathrm{Z}=$ Tingkat keyakinan penentuan sampel $95 \%$ atau 1,96

Moe $=$ Tingkat kesalahan maksimum yang bisa ditoleransi, biasanya $10 \%$

Maka dari perhitungan rumus diperoleh:

$$
\begin{gathered}
n=\frac{1,96^{2}}{4(0,1)^{2}} \\
n=\frac{3,8416}{0,4} \\
n=96,04
\end{gathered}
$$

Jumlah sampel yang dibutuhkan dalam penelitian ini adalah 96,04. Jadi, jumlah sampel yang diambil adalah minimal 96 namun untuk memudahkan maka dibulatkan menjadi 100. Teknik pengambilan sampel yang digunakan adalah non probabilitas dengan teknik purposive sampling. Teknik ini dipilih untuk memastikan bahwa hanya sampel yang memiliki kriteria tertentu yang telah ditetapkan oleh peneliti yang akan diambil sebagai sampel (Black dan Champion, 2001). Kriteria yang ditetapkan untuk sampel yang akan digunakan adalah:

1. Berusia 15 s.d. 25 tahun.

2. Pernah melakukan transaksi di Marketplace Shopee minimal 2 kali dalam satu bulan. Jenis data yang digunakan dalam penelitian ini adalah data kuantitatif. Sumber data yang digunakan adalah data primer. Data primer dari penelitian ini diperoleh langsung dari pengisian kuesioner yang dibagikan kepada responden yang telah melakukan transaksi secara online di marketplace Shopee.

Metode pengumpulan data yang digunakan dalam penelitian ini adalah teknik survei dengan metode kuisioner. Metode pengukuran kuesioner pada penelitian ini menggunakan Skala Likert. Menurut Ghozali (2011), Skala Likert adalah skala yang berisi lima tingkat preferensi jawaban dengan pilihan (1) Sangat Tidak Setuju (STS), (2) Tidak Setuju (TS), (3) Netral (N), (4) Setuju (S), dan (5) Sangat Setuju (SS).

Analisis Regresi Linear Berganda digunakan untuk mengukur pengaruh antara lebih dari satu variabel prediktor (variabel bebas) terhadap variabel terikat. Analisis Regresi Linier Berganda bertujuan untuk mengetahui pengaruh Online Consumer review dan Influencer terhadap keputusan pembelian. Persamaan regresi dalam penelitian ini adalah:

Keterangan :

$$
\mathrm{Y}=\alpha+\beta 1 \mathrm{X} 1+\beta 2 \mathrm{X} 2+\mathrm{e}
$$

$\mathrm{Y}=$ Keputusan Pembelian

$\alpha=$ Konstanta

$\mathrm{X} 1$ = Online Consumer Review

$\mathrm{X} 2=$ Influencer

b1 = Koefisien regresi variabel Online Consumer Review

b2 = Koefisien regresi variabel kualitas Influencer

$\mathrm{e}=$ Standard Error 
Dari olah data yang dilakukan maka diperoleh hasil penelitian beserta pembahasannya sebagai berikut:

\section{Identitas Responden}

Berdasarkan 100 data kuesioner, diperoleh informasi mengenai identitas responden yang menjadi sampel penelitian. Demografi responden dalam penelitian ini berupa jenis kelamin dan usia. Secara lebih rinci demografi responden dapat dlihat pada tabel 2 berikut :

Tabel 2. Demografi Responden

\begin{tabular}{lcc}
\hline Ketrangan & Jumlah (orang) & Presentase(\%) \\
\hline Jenis kelamin & 58 & $58 \%$ \\
Perempuan & 42 & $42 \%$ \\
Laki-laki & & \\
\hline Usia & 31 & $31 \%$ \\
15 s.d. 20 tahun & 69 & $69 \%$ \\
21 s.d. 25 tahun & &
\end{tabular}

Sumber: Data primer yang diolah, 2020.

Dari tabel 2 diatas dapat dilihat dari jenis kelamin memiliki persentase yang berbeda antara perempuan dan laki-laki, persentase responden dengan jenis kelamin perempuan $58 \%$ dan untuk jenis kelamin laki-laki $42 \%$. Sedangkan jika dilihat dari kelompok usia sebagian besar responden masuk dalam kelompok usia 21 s,d. 25 tahun dengan persentase $69 \%$ dan sisanya termasuk dalam kelompuk usia 15 s.d. 20 tahun dengan persentase $31 \%$.

\section{Analisis Statistik Deskriptif}

Untuk memberikan gambaran mengenai variabel penelitian, yang digunakan dalam penelitian ini yaitu Online Consumer Review, Influencer dan Keputusan Pembelian akan dipaparkan dalam tabel statistik deskriptif yang memperlihatkan Nilai skor rata-rata variabel, yang disajikan dalam tabel berikut ini : 
Tabel 3. Hasil Statistik Deskriptif Online consumer review

\begin{tabular}{|c|c|c|c|c|c|}
\hline $\begin{array}{c}\text { Item } \\
\text { Kuesioner }\end{array}$ & $\mathbf{N}$ & Pernyataan & $\begin{array}{l}\text { Total } \\
\text { Skor }\end{array}$ & $\begin{array}{l}\text { Rata- } \\
\text { rata } \\
\text { Skor }\end{array}$ & $\begin{array}{c}\text { Skor } \\
\text { Rata- } \\
\text { rata } \\
\text { Variabel }\end{array}$ \\
\hline X1.1 & 100 & Menurut saya Ulasan online sangat informatif & 435 & 4,35 & \\
\hline $\mathrm{X} 1.2$ & 100 & Menurut saya Ulasan online sangat membantu & 449 & 4,49 & \\
\hline $\mathrm{X} 1.3$ & 100 & $\begin{array}{l}\text { Menurut saya Ulasan online tentang produk } \\
\text { patut diketahui. }\end{array}$ & 448 & 4,48 & \\
\hline $\mathrm{X} 1.4$ & 100 & $\begin{array}{l}\text { Menurut saya Ulasan sesuai untuk kebutuhan } \\
\text { saya. }\end{array}$ & 417 & 4,17 & \\
\hline $\mathrm{X} 1.5$ & 100 & $\begin{array}{l}\text { Menurut saya Ulasan online merupakan } \\
\text { informasi terkini. }\end{array}$ & 425 & 4,25 & \\
\hline $\mathrm{X} 1.6$ & 100 & $\begin{array}{l}\text { Menurut saya Ulasan online memberikan } \\
\text { informasi yang benar. }\end{array}$ & 382 & 3,82 & \\
\hline $\mathrm{X} 1.7$ & 100 & $\begin{array}{l}\text { Menurut saya Ulasan berisi semua informasi } \\
\text { yang diperlukan tentang produk yang ditinjau. }\end{array}$ & 409 & 4,09 & 4.25 \\
\hline $\mathrm{X} 1.8$ & 100 & $\begin{array}{l}\text { Menurut saya Ulasan online berisi informasi } \\
\text { yang sangat rinci tentang produk / layanan } \\
\text { yang ditinjau. }\end{array}$ & 399 & 3,99 & \\
\hline $\mathrm{X} 1.9$ & 100 & $\begin{array}{l}\text { Ulasan negatif mengurangi minat saya terhadap } \\
\text { produk }\end{array}$ & 438 & 4,38 & \\
\hline $\mathrm{X} 1.10$ & 100 & $\begin{array}{l}\text { Banyak ulasan negatif membuat saya memilih } \\
\text { untuk mencari produk lain }\end{array}$ & 452 & 4,52 & \\
\hline $\mathrm{X} 1.11$ & 100 & Pengulas secara positif menilai produk tertentu & 423 & 4,23 & \\
\hline $\mathrm{X} 1.12$ & 100 & $\begin{array}{l}\text { Secara umum, pengulas merekomendasikan } \\
\text { produk tertentu }\end{array}$ & 421 & 4,21 & \\
\hline
\end{tabular}

Sumber: Data primer yang diolah, 2020.

Dari tabel 3 berdasarkan atas pernyataa dari kuesioner yang didesain dengan menggunakan skala likert, kisaran teoritis variabel Online consumer Review yang memiliki instrumen dengan 12 butir pernyataan dapat diketahui skor rata-rata variabel Online consumer Review sebesar 4,25 menunjukkan bahwa rata-rata jawaban responden terhadap variabel Online consumer Review yaitu setuju. Pernyataan X1.10 yaitu, "Banyak ulasan negatif membuat saya memilih untuk mencari produk lain" dengan rata-rata skor 4,52 merupakan pernyataan dengan skor tertinggi pada variabel Online Consumer Review, yang berarti bahwa rata-rata pendapat responden mendekati sangat setuju bahwa Banyak ulasan negatif akan mempengaruhi mereka untuk mencari produk lain. 
Tabel 4. Hasil Statistik Deskriptif influencer (X2)

\begin{tabular}{|c|c|c|c|c|c|}
\hline $\begin{array}{l}\text { Item } \\
\text { Kuesioner }\end{array}$ & $\mathbf{N}$ & Pernyataan & $\begin{array}{l}\text { Total } \\
\text { Skor }\end{array}$ & $\begin{array}{l}\text { Rata- } \\
\text { rata } \\
\text { Skor }\end{array}$ & $\begin{array}{l}\text { Skor Rata- } \\
\text { rata } \\
\text { Variabel }\end{array}$ \\
\hline $\mathrm{X} 2.1$ & 100 & $\begin{array}{l}\text { Saya percaya dengan influencer yang } \\
\text { memiliki pengetahuan tentang produk }\end{array}$ & 403 & 4.03 & \\
\hline $\mathrm{X} 2.2$ & 100 & $\begin{array}{l}\text { Saya percaya dengan influncer yang memiliki } \\
\text { pengalaman dengan produk }\end{array}$ & 414 & 4.14 & \\
\hline $\mathrm{X} 2.3$ & 100 & $\begin{array}{l}\text { Saya percaya dengan influencer yang jujur } \\
\text { dalam merekomendasikan produk }\end{array}$ & 429 & 4.29 & \\
\hline $\mathrm{X} 2.4$ & 100 & $\begin{array}{l}\text { Saya percaya dengan influencer yang dapat } \\
\text { diandalkan. }\end{array}$ & 414 & 4.14 & \\
\hline $\mathrm{X} 2.5$ & 100 & Saya Percaya dengan influencer yang tulus. & 414 & 4.14 & 4.03 \\
\hline $\mathrm{X} 2.6$ & 100 & $\begin{array}{l}\text { Saya menyukai influencer yang memiliki } \\
\text { nilai dan keyakinan yang sama. }\end{array}$ & 405 & 4.05 & \\
\hline $\mathrm{X} 2.7$ & 100 & $\begin{array}{l}\text { Saya menyukai influencer yang memiliki } \\
\text { kesamaan selera dan preferensi. }\end{array}$ & 419 & 4.19 & \\
\hline $\mathrm{X} 2.8$ & 100 & Saya Menyukai influencer yang populer & 389 & 3.89 & \\
\hline $\mathrm{X} 2.9$ & 100 & Saya menyukai influencer secara fisik & 351 & 3.51 & \\
\hline $\mathrm{X} 2.10$ & 100 & $\begin{array}{l}\text { Saya Menyukai influencer yang memiliki } \\
\text { kharisma }\end{array}$ & 389 & 3.89 & \\
\hline
\end{tabular}

Sumber: Data primer yang diolah, 2020.

Dari tabel 4 berdasarkan atas pernyataan dari kuesioner yang didesain dengan menggunakan skala likert, kisaran teoritis variabel Influencer yang memiliki instrumen dengan 10 butir pernyataan dapat diketahui skor rata-rata variabel Influencer sebesar 4,03 menunjukkan bahwa rata-rata jawaban responden terhadap variabel Influencer yaitu setuju. Pernyataan X2.3 yaitu, "Saya percaya dengan influencer yang jujur dalam merekomendasikan produk dengan skor 4,29 merupakan pernyataan dengan skor tertinggi pada variabel Influencer maka dapat dikatakan bahwa rata-rata responden setuju bahwa mereka percaya dengan influencer yang jujur dalam merekomendasikan produk.

Tabel 5. Hasil Statistik Deskriptif Keputusan Pembelian (Y)

\begin{tabular}{|c|c|c|c|c|c|}
\hline $\begin{array}{c}\text { Item } \\
\text { Kuesioner }\end{array}$ & $\mathbf{N}$ & Pernyataan & $\begin{array}{l}\text { Total } \\
\text { Skor }\end{array}$ & $\begin{array}{l}\text { Rata- } \\
\text { rata } \\
\text { Skor }\end{array}$ & $\begin{array}{c}\text { Skor } \\
\text { Rata- } \\
\text { rata } \\
\text { Variabel }\end{array}$ \\
\hline Y.1 & 100 & $\begin{array}{l}\text { Saya berniat membeli produk yang telah saya } \\
\text { baca ulasan online positifnya }\end{array}$ & 435 & 4.35 & \multirow{4}{*}{4.32} \\
\hline Y.2 & 100 & $\begin{array}{l}\text { Jika seseorang meminta saran saya untuk } \\
\text { membeli produk, saya akan merekomendasikan } \\
\text { produk telah saya baca ulasan onlinenya }\end{array}$ & 423 & 4.23 & \\
\hline Y.3 & 100 & $\begin{array}{l}\text { Sebagai prinsip, saya memberi tahu diri saya } \\
\text { sebelum membeli produk untuk melihat ulasan } \\
\text { online Untuk membantu }\end{array}$ & 427 & 4.27 & \\
\hline Y.4 & 100 & $\begin{array}{l}\text { Di masa mendatang, saya akan membeli } \\
\text { produk yang telah saya baca ulasan onlinenya }\end{array}$ & 444 & 4.44 & \\
\hline
\end{tabular}

Sumber: Data primer yang diolah, 2020. 
Dari Tabel 5 berdasarkan atas pernyataan dari kuesioner yang didesain dengan menggunakan skala likert, kisaran teoritis variabel keputusan pembelian yang memiliki instrumen dengan 4 butir pernyataan dapat diketahui skor rata-rata variabel keputusan pembelian sebesar 4,32 menunjukkan bahwa rata-rata jawaban responden terhadap variabel keputusan pembelian adalah setuju. Pernyataan Y4 yaitu, "Di masa mendatang, saya akan membeli produk yang telah saya baca ulasan onlinenya dengan skor 4,44 merupakan pernyataan dengan skor tertinggi pada variabel keputusan pembelian, yang berarti bahwa rata-rata responden setuju bahwa mereka pada masa mendatang, akan membeli produk yang telah dibaca ulasan onlinenya.

Uji validitas digunakan untuk mengukur sah atau valid tidaknya suatu kuesioner. Suatu kuesioner dikatakan valid jika pertanyaan dan kuesioner mampu untuk mengungkap sesuatu yang akan diukur oleh kuesioner tersebut (Ghozali, 2006). Uji validitas menggunakan analisis korelasi pearson. Jika pada tingkat signifikan 5\% nilai $\mathrm{r}$ hitung $>\mathrm{r}$ tabel maka dapat disimpulkan bahwa butir instrumen tersebut valid.Hasil Pengujian validitas data dapat dilihat pada Tabel 6 berikut ini:

Tabel 6. Hasil Uji Validitas data

\begin{tabular}{|c|c|c|c|c|}
\hline Variabel & Indikator & r-hitung & r-tabel & Keterangan \\
\hline \multirow{12}{*}{$\begin{array}{c}\text { Online Consumer Review } \\
\text { (X1) }\end{array}$} & $\mathbf{O}$ & 0.530 & 0.1966 & VALID \\
\hline & X1.2 & 0.654 & 0.1966 & VALID \\
\hline & $\mathrm{X} 1.3$ & 0.534 & 0.1966 & VALID \\
\hline & X1.4 & 0.502 & 0.1966 & VALID \\
\hline & X1.5 & 0.560 & 0.1966 & VALID \\
\hline & X1.6 & 0.615 & 0.1966 & VALID \\
\hline & X1.7 & 0.673 & 0.1966 & VALID \\
\hline & X1.8 & 0.675 & 0.1966 & VALID \\
\hline & X1.9 & 0.429 & 0.1966 & VALID \\
\hline & X1.10 & 0.540 & 0.1966 & VALID \\
\hline & X1.11 & 0.694 & 0.1966 & VALID \\
\hline & $\mathrm{X} 1.12$ & 0.684 & 0.1966 & VALID \\
\hline \multirow{10}{*}{$\begin{array}{l}\text { Influencer } \\
\text { (X2) }\end{array}$} & X2.1 & 0.456 & 0.1966 & VALID \\
\hline & $\mathrm{X} 2.2$ & 0.568 & 0.1966 & VALID \\
\hline & $\mathrm{X} 2.3$ & 0.657 & 0.1966 & VALID \\
\hline & $\mathrm{X} 2.4$ & 0.682 & 0.1966 & VALID \\
\hline & $\mathrm{X} 2.5$ & 0.696 & 0.1966 & VALID \\
\hline & X2.6 & 0.611 & 0.1966 & VALID \\
\hline & $\mathbf{X} 2.7$ & 0.713 & 0.1966 & VALID \\
\hline & $\mathrm{X} 2.8$ & 0.514 & 0.1966 & VALID \\
\hline & X2.9 & 0.586 & 0.1966 & VALID \\
\hline & X2.10 & 0.621 & 0.1966 & VALID \\
\hline \multirow{4}{*}{$\begin{array}{c}\text { Impulse Buying } \\
\text { (Y) }\end{array}$} & Y1 & 0.698 & 0.1966 & VALID \\
\hline & Y2 & 0.713 & 0.1966 & VALID \\
\hline & Y3 & 0.742 & 0.1966 & VALID \\
\hline & Y4 & 0.764 & 0.1966 & VALID \\
\hline
\end{tabular}

Sumber: Data primer yang diolah, 2020. 
Dari tabel 6 diketahui bahwa semua nilai r hitung dari variabel Online Consumer Review, Influencer dan Keputusan Pembelian $>$ dari nilai $\mathrm{r}$ tabel menunjukkan data variabel Online Consumer Review, Influencer dan Keputusan Pembelian semuanya valid.

Reliabilitas adalah alat untuk mengukur suatu kuesioner yang merupakan indikator dari suatu variabel. Suatu kuesioner dikatakan reliabel atau handal jika jawaban pertanyaan adalah konsisten atau stabil dari waktu ke waktu (Ghozali,2006). Pengukuran reliabilitas dalam penelitian ini dengan uji statistik Cronbach Alpha (a). Suatu variabel dikatakan reliabel jika nilai Cronbach Alpha (a) > 0,6 . Semakin nilai alpanya mendekati satu maka nilai reliabilitas datanya semakin terpercaya. Hasil pengujian reliabilitas dapat dilihat pada Tabel 7 dibawah ini :

Tabel 7. Hasil Uji Reliabilitas

\begin{tabular}{|c|c|c|c|c|}
\hline No. & Variabel & $\begin{array}{l}\text { Nilai } \\
\text { Alpha }\end{array}$ & Cronbach & Keterangan \\
\hline 1. & $\begin{array}{l}\text { Online Consumer } \\
\text { Review }\end{array}$ & $\mathbf{0 , 8 3 0}$ & & Reliabel \\
\hline 2. & Influencer & 0,809 & & Reliabel \\
\hline 3. & $\begin{array}{l}\text { Keputusan } \\
\text { Pembelian }\end{array}$ & 0,704 & & Reliabel \\
\hline
\end{tabular}

Sumber: Data primer yang diolah, 2020.

Dapat dilihat dari Tabel 7 bahwa semua variabel baik itu Online Consumer Review, Influencer dan Keputusan Pembelian semuanya reliabel, hal ini terlihat dari nilai cronbach alpha dari variabel Online Consumer Review, Influencer dan Keputusan Pembelian memiliki nilai diatas 0,6.

Tabel 8. Hasil Uji Normalitas

\begin{tabular}{ll}
\hline Asymp Sig (2-tailed) & Keterangan \\
\hline $\mathbf{0 . 6 1 3}$ & Normal \\
\hline
\end{tabular}

Pengujian normalitas ini dilakukan dengan menggunakan One Sample Kolmogorof-Smirnov Test. Uji normalitas bertujuan untuk menguji apakah dalam model regresi, variabel penganggu atau residual memiliki distribusi normal (Ghozali, 2016). Data berdistribusi normal jika nilai Asymp Sig (2-tailed) yang dihasilkan lebih besar dari nilai alpha yaitu sebesar 0,05 (5\%). Sesuai dengan dasar pengambilan keputusan dalam uji Kolmogorof-Smirnov, maka dapat dikatakan bahwa data penelitian ini berdistribusi normal

\section{Uji Multikolinearitas}

Bertujuan untuk menguji apakah model regresi ditemukan adanya korelasi antar variabel bebas (Independen). Dalam penelitian ini teknik untuk mendeteksi ada tidaknya multikolinearitas didalam model regresi dapat dilihat dari nilai tolerance dan Variance inflation factor (VIF), nilai tolerance yang besarnya diatas 0,10 dan nilai VIF dibawah 10 menunjukkan bahwa tidak ada multikolinearitas diantara variabel bebasnya (Ghozali, 2006). 
Tabel 9. Hasil Uji Multikolinearitas

\begin{tabular}{|c|c|c|c|}
\hline \multirow{2}{*}{ Variabel } & \multicolumn{2}{|c|}{ Collenearity Statistics } & \multirow[t]{2}{*}{ Keterangan } \\
\hline & Tolerance & VIF & \\
\hline $\begin{array}{l}\text { Online Consumer } \\
\text { Review }\end{array}$ & 0,786 & 1,273 & Bebas multikolinearitas \\
\hline Influencer & 0,786 & 1,273 & \\
\hline
\end{tabular}

Sumber: Data primer yang diolah, 2020.

Dari tabel 9 diketahui bahwa semua variabel yaitu Online Consumer Review,

Influencer memiliki nilai tolerance $>0.10$ dan nilai VIF $<10$, sehingga semua variabel bebas dari masalah multikolinearitas.

\section{Uji Heteroskedastisitas}

Uji heteroskedastisitas bertujuan untuk menguji apakah dalam model regresi terjadi ketidaksamaan variance dari residual satu pengamatan ke pengamatan yang lain. Jika variance dari residual satu pengamatan ke pengamatan yang lain tetap, maka disebut homoskedastisitas dan jika berbeda disebut heteroskedastisitas. Model regresi yang baik adalah yang homoskedastisitas atau tidak terjadi heteroskedastisitas. Hasil Uji heteroskedastisitas dapat dilihat pada tabel berikut ini:

Tabel 10. Hasil Uji Heteroskedastisitas

\begin{tabular}{lllll}
\hline Variabel & koefisien & $\mathrm{T}$ & Sig & Keterangan \\
\hline $\begin{array}{l}\text { Online consumer } \\
\text { Review }\end{array}$ & $-0,006$ & $-0,308$ & 0,759 & $\begin{array}{l}\text { Tidak terjadi } \\
\text { masalah } \\
\text { heteroskedastisitas }\end{array}$ \\
Influencer & 0,009 & 0,447 & 0,656 & \\
\hline
\end{tabular}

Sumber: Data primer yang diolah, 2020.

Dari tabel 10 diketahui bahwa untuk semua variabel memiliki nilai signifikansi lebih dari 0.05, sehingga variabel Online Consumer Review dan Influencer tidak terjadi masalah heteroskedastisitas.

Pengujian hipotesis dalam penelitian ini menggunakan analisis regresi berganda (Multiple regression analysis). Hasil pengujian untuk hipotesis 1 dan 2

Tabel 11. Hasil Uji Analisi Regresi linier Berganda

\begin{tabular}{lllll}
\hline \multicolumn{1}{c}{ Variabel } & Nilai koefisien & $\begin{array}{c}\text { Persamaan 1 } \\
\text { t-statistik }\end{array}$ & Sig & $\begin{array}{l}\text { Konfirmasi } \\
\text { Hipotesis }\end{array}$ \\
\hline Constanta & $\mathbf{6 , 3 9 4}$ & $\mathbf{5 , 5 7 3}$ & $\mathbf{0 , 0 0 0}$ & Diterima \\
$\begin{array}{l}\text { Online } \\
\text { Consumer }\end{array}$ & $\mathbf{0 , 1 8 0}$ & & & \\
$\begin{array}{l}\text { Review } \\
\text { Influencer }\end{array}$ & $\mathbf{0 , 0 4 2}$ & $\mathbf{1 , 2 3 2}$ & $\mathbf{0 , 2 2 1}$ & Ditolak \\
R Square & $\mathbf{0 , 3 3 8}$ & & & \\
Adjusted & $\mathbf{0 , 3 2 4}$ & & & \\
R Square & & & \\
$\mathbf{F}$ & $\mathbf{2 4 , 7 7 4}$ & & \\
Sig & $\mathbf{0 , 0 0 0}$ & & \\
\hline \multicolumn{2}{c}{ Sumber: Data primer yang diolah, 2020. } \\
\hline
\end{tabular}


Dari tabel 11 di atas yang merupakan hasil regresi diketahui bahwa nilai Adjusted R Square sebesar 0,324 menunjukan bahwa 32,4 \% variabel Keputusan pembelian dapat dijelaskan oleh variabel Online Consumer Review, sedangkan 67,6\% dapat dijelaskan oleh variabel lain yang tidak ada dalam persamaan yang di gunakan .Dapat dilihat juga Nilai statistik F sebesar 24,774 dengan nilai signifikansi $0,000<$ 0,05 menunjukkan bahwa model yang digunakan dalam penelitian layak dan menunjukkan bahwa secara simultan variabel independen Mempengaruhi variabel dependen.

\section{Persamaan regresi dalam penelitian ini :}

$\mathrm{Y}=6,394+0,180 \times 1+0,042 X 2+e$

Hipotesis pertama dalam penelitian ini adalah Online Consumer review berpengaruh positif dan signifikan terhadap Keputusan pembelian. Hasil pengujian menunjukkan nilai koefisien b1 sebesar 0,180 dengan nilai signifikansi $0,000<0,05$ yang berarti bahwa terdapat pengaruh positif antara variabel Online Consumer Review terhadap variabel Keputusan pembelian. Nilai t-hitung untuk variabel Online consumer review sebesar 5,573 sedangkan t-tabel sebesar 1,984. Jika t-hitung > t-tabel maka nilai signifikannya lebih kecil dari 0,05 (5\%) dan menunjukkan hipotesis di terima , artinya hipotesis pertama dalam penelitian ini yang mengatakan bahwa Online consumer review berpengaruh positif dan signifikan terhadap keputusan pembelian produk di Marketplace Shopee diterima

Hipotesis kedua dalam penelitian ini adalah Influencer berpengaruh terhadap Keputusan pembelian. Hasil pengujian menunjukkan nilai koefisien b2 sebesar 0,042 dengan nilai signifikansi $0,221>0,05$ yang berarti bahwa tidak terdapat pengaruh antara variabel Influencer terhadap variabel Keputusan pembelian . Nilai t-hitung untuk variabel Influencer sebesar 1,232 sedangkan t-tabel sebesar 1,984. Menunjukan t-hitung < t-tabel maka nilai signifikannya lebih besar dari $0,05(5 \%)$ artinya hipotesis kedua dalam penelitian ini yang menyatakan Influencer berpengaruh positif dan signifikan terhadap keputusan pembelian produk di Marketplace Shopee ditolak

Berdasarkan hasil pengujian dari hipotesis pertama menunjukkan Online Consumer Review berpengaruh positif dan signifikan terhadap keputusan Pembelian produk di Marketplace SHOPEE .dari hasil jawaban yang diberikan responden melalui kuesioner didapatkan bahwa rata-rata responden memilih setuju dan sangat setuju bahwa Online consumer review bersifat informatif, membantu, serta patut diketahui dan rata-rata juga menjawab setuju dan sangat setuju bahwa banyaknya ulasan negatif membuat mereka memilih untuk mencari produk lain.

Hasil pengujian pertama ini sejalan dengan hasil dari pengujian penelitian terdahulu yang juga mendukung pengaruh Online Consumer Review terhadap keputusan pembelian yakni penelitian yang dilakukan oleh Thomas, et.al. (2019) yang juga meneliti mengenai ulasan online consumer review mendapatkan hasil penelitian yaitu dimensi kualitas argumen dan isyarat periferal memberikan pengaruh mereka secara bersamaan, memiliki dampak langsung positif pada manfaat yang dirasakan dari ulasan online dan pengaruh tidak langsung positif pada niat pembelian penerima.

Berdasarkan hasil pengujian dari hipotesis kedua menunjukkan influencer tidak berpengaruh terhadap keputusan Pembelian produk di Marketplace Shopee melihat dari hasil jawaban yang diberikan responden melalui kuesioner ternyata sebagian menjawab setuju dan sangat setuju namun cukup banyak juga dari responden yang menjawab netral mengenai pengetahuan, kejujuran, keandalan dan kepopuleran dari Influencer, dan juga 
sebagian kecil menjawab tidak setuju mengenai faktor fisik dan kepopuleran dari influencer.

Hasil pengujian kedua tidak sejalan dengan hipotesis kedua yang mengatakan bahwa Influencer berpengaruh positf dan signifikan terhadap keputusan pembelian produk di Marketplace Shopee. Hal ini juga di jelaskan Menurut peneliatan kualitatif terdahulu yang berjudul Meningkatkan Daya Saing UKM Dengan Penggunaan Iklan Influencer Instagram dan E-Wom oleh Anastasia Konstantopoulou, Ioannis Rizomyliotis, Kleopatra Konstantoulaki dan Raghad Badahdah (2012) hasil wawancara mereka menyebutkan bahwa para peserta cukup skeptis (ragu-ragu ) ketika menerima ulasan atau promosi dari influencer kecantikan karena mereka tidak selalu menganggapnya otentik. Dan, mereka perlu melakukan riset sendiri juga. Temuan menunjukkan bahwa mereka (konsumen )mencari tanda untuk melihat apakah influencer Instagram kecantikan itu independen atau disponsori oleh suatu merek.

\section{KESIMPULAN DAN SARAN}

Dari data yang didapatkan dan analisis yang telah dilakukan dalam penelitian ini maka yang dapat disimpulkan adalah :

a. Penelitian ini membuktikan bahwa Online Consumer Review mempengaruhi Keputusan Pembelian produk di Marketplace Shopee.

b. Penelitian ini menunjukan bahwa Influencer tidak mempengaruhi keputusan pembelian produk di Marketplace Shopee.

\section{UCAPAN TERIMA KASIH}

Terima kasih kepada berbagai pihak, yang telah membantu peneliti dalam melaksanakan penelitian ini hingga selesai. Bantuan yang diberikan berupa dana, pemikiran, dan support yang berharga dan tidak dapat disebutkan satu persatu.. 


\section{DAFTAR PUSTAKA}

A.Black, James Dan Dean Jean J. Champion. 2001, Metode Dan Masalah Penelitian Sosial. Terjemahan Oleh E. Koswara Dkk, Bandung: Reefika Aditama.

Agustina, Lydia, Alifia Oktrina Fayardi Dan Irwansyah (2018) Online Review: Indikator penilaian kredibilitas Online dalam Platform E-Commerce, Jurnal ilmu komunikasi Volume15,No2

Ajzen, I. (1985). From Intentions To Actions: A Theory Of Planned Beha-Vior". In J. Kuhl And J. Beckman (Eds.), Action-Control: From Cognition To Beha-Vior (Hal. 11-39). Heidelberg: Springer, diunduh dari Http://People.Umass. Edu/Aizen Pada Nov, 17, 2006

Ajzen, I. (2005). Attitudes, Personality And Behavior, (2nd Edition), Berkshire, UK: Open University Press-Mcgraw Hill Education.

Badan Pusat Statistik . 2018 . Jumlah Penduduk Sumatra Selatan. Https://Sumsel.Bps.Go.Id/Subject/12/Kependudukan.Html\#Subjekviewtab3, di Akses 12 Oktober 2019

Booth,N.And Julie Ann Matic(2011) "Mapping And Leveraging Influencers In Social Media To Shape Corporate Brand Corporate Perceptions Communications:" An International Journal vol. 16 No. 3, 2011 Pp. 184-191

Cheung, Christy M.K; Matthew K.O. Lee And Neil Rabjohn.2008. "The Impact Of Electronic Word-Of-Mouth, The Adoption Of Online Opinions In Online Customer Communities". Article In Internet Research. Vol. 18 No. 3, Pp. 229-247

Cheung, R. (2014) 'The Influence Of Electronic Word-Of-Mouth On Information Adoption In Online Customer Communities', Global Economic Review, Vol. 43, No. 1, Pp.42-57.

CNN Indonesia. 2019. Indonesia Kuasai Duapertiga Total Transaksi Shopee. Https://Www.Cnnindonesia.Com/Teknologi/20190531063221-185-399896/IndonesiaKuasai-Duapertiga-Total-Transaksi-Shopee [Diakses 19 oktober 2020 ]

Debora, Yantina. 2016. Berapa Besar Pengaruh Ulasan Pembeli Saat Berbelanja Online?Https://Tirto.Id/Berapa-Besar-Pengaruh-Ulasan-Pembeli-Saat-BerbelanjaOnline-b7Gm, diakses 25 oktober 2019.

Erkan,Ismail And Chris Evans (2015) The Influences Of Ewom In Social Media On Consumer Purchase Intentions: An Extended Approach To Information Adoption".Computers In Human Behaviour 61.

Febriana M Dan Edyyulianto (2018) Pengaruh Online Consumer Review Oleh Beauty Vlogger terhadap keputusan pembelian (Survei pada mahasiswi fakultas ilmu administras iuniversitas brawijaya angkatan 2014/2015 Dan 2015/2016 Yang Membeli Dan Menggunakanpurbasari Matte Lipstick), Jurnaladministrasibisnis (Jab), Vol. 58 No. 1 Hal 3 
Feldman, Robert S. 1995. Social Psychology. New Jersey : A Simon \& Schuster Company. Englewood Cliffs

Ferdinand, Augusty. (2002). Pengembangan Minat Beli Merek Ekstensi. Semarang : Badan Penerbit Universitas Diponegoro.

Filieri, R. And Mcleay, F. (2013) 'E-WOM And Accommodation: An Analysis Of The Factors That Influence Travelers' Adoption Of Information From Online Reviews', Journal Of Travel Research,Vol. 53, No. 1, Pp.44-57

Fishbein, M., \& Ajzen, I. (1975). Belief, Attitude, Intention, And Behavior: An Introduction To Theory And Research, Reading, MA: Addison-Wesley

Ghozali, Imam. 2006. Aplikasi Analisis Multivariate Dengan Program Spss. Cetakan Keempat. Semarang: Badan Penerbit Universitas Diponegoro.

Ghozali, Imam. 2011. “Aplikasi Analisis Multivariate Dengan Program Spss”. Semarang: Badan Penerbit Universitas Diponegoro.

Haryanto, Agus Tri. 2019. Pengguna Internet Indonesia Didominasi Milenial. Https://Inet.Detik.Com/Telecommunication/D-4551389/Pengguna-Internet-IndonesiaDidominasi-Milenial. Di Akses 7 Oktober 2019.

Iprice. 2019. Peta E-Commerce Indonesia. Https://Iprice.Co.Id/Insights/Mapofecommerce. Diakses 15 Oktober 2019.

Jamil, R.A. And Hasnu, S.A.F. (2013) 'Consumer's Reliance On Word Of Mouse: Influence On Consumer's Decision In An Online Information Asymmetry Context', Journal Of Business \& Economics, Vol. 5, No. 2, Pp.171-205.

Jayani, Dwi Hadya. 2019. Shopee Jadi E-Commerce Paling Top Dari Masa Ke Masa Top ECommerce Berdasarkan Ranking Playstore Kuartal I 2017Kuartal2019.Https://Databoks.Katadata.Co.Id/Datapublish/2019/09/03/Shopee-Jadi-ECommerce-Paling-Top-Dari-Masa-Ke-Masa, diakses 20 oktober 2019

Kamila , Korina Tasya ,. Suharyono., Dan Inggang Perwangsa Nuralam . (2019). Pengaruh Online Consumer Review Terhadap Keputusan Pembelian (Survei Pada Mahasiswa Universitas Brawijaya Ta 2015/2016 - 2018/2019 Yang Pernah Membeli Dan Menggunakan Xiaomi Smartphone),Jurnal Administrasi Bisnis. Vol. 72 No. 1

Khammash, M. (2008) “Electronic Word-Of mouth: Antecedents Of Reading Customer Reviews In On-Line Opinion Platforms: A Quantitative Study From The UK Market".ADIS International Conference

Kharis (2011). Loyalitas Pelanggan: Sebuah Kajian Konseptual Sebagai Panduan Bagi Penalty, Jurnal Ekonomi Dan Bisnis Indonesia 
Konstantopoulou, A., Rizomyliotis, I., Konstantoulaki, K. and Badahdah, R. (2019 )"Improving Smes' Competitiveness With The Use Of Instagram Influencer Advertising And Ewom" International Journal Of Organizational Analysis,Vol. 27 No. 2, Pp. 315317

Kotler, Phillip Dan Keller. 2009, Manajemen Pemasaran, Edisi 13, Jilid 1, Jakarta: PT.Indeks.

Kotler, Philip Dan Keller. 2016. Marketing Management, 15th Edition. United States: Pearson Education

Luo, C., Luo, X., Schatzberg, L. And Sia, C.L. (2013) 'Impact Of Informational Factors On Online Recommendation Credibility: The Moderating Role Of Source Credibility', Decision Support Systems, December, Vol. 56, Pp.92-102.

Peter, J Paul Dan Olson, Jerry C., Consumer Behavior: Perilaku Konsumen Dan Strategi Pemasaran, Edisi Keempat, Erlangga.

Pratisti, Rati . 2016. Inilah Perbedaan Online Shop, E-Commerce, Dan Marketplace Yang Perlu Kamu Ketahui. Https://Teknonisme.Com/Inilah-Perbedaan-Online-Shop-ECommerce-Dan-Marketplace-Yang-Perlu-Kamu-Ketahui, diakses 13 oktober 2019

Priansa, Doni Junni (2016) Pengaruh E-Wom Dan Persepsi nilai terhadap keputusan konsumen untuk berbelanja Online Di Lazada, Ecodemica, Vol. IV, No.1

Reichelt, Jonas , Jens Sievert And Frank (2013 )“ How Credibility Affects Ewom Reading: The Influences Of Expertise, Trustworthiness, And Similarity On Utilitarian And Social Functions" Journal Of Marketing Communications, Vol. 20, Nos. 1-2, 65-81

Shimp, Terence. 2007. Periklanan Promosi ( Aspek Tambahan Komunikasi Pemasaran Terpadu). Jilid Kesatu, Edisi Terjemahan. Jakarta: Erlangga.

Skalanews. 2019. Kemkominfo: Pertumbuhan E-Commerce Indonesia Capai 78 Persen Https://Kominfo.Go.Id/Content/Detail/16770/Kemkominfo-Pertumbuhan-E-CommerceIndonesia-Capai-78-Persen/0/Sorotan_Media. Diakses 15 oktober 2020.

Sugiharto. S.A, Dan Maulana Rezi Ramadhana( 2018) Pengaruh kredibilitas Influencer Terhadap sikap pada merek, Studi pada mahasiswa fakultas komunikasi Dan Bisnisuniversitas Telkom, Jurnalilmupolitik Dan Komunikasi, Volume VIII, No. 2

Sugiyono. 2012. Metode Penelitian Kuantitatif, Kualitatif Dan R\&D (Metode Penelitian Dan Pengembangan). Bandung: Alfabeta.

Sugiyono. 2015. Metode Penelitian Pendidikan (Pendekatan Kuantitatif, Kualitatif Dan R\&D). Penerbit CV. Alfabeta: Bandung.

Sutanto, Monica Adhelia dan Atik Aprianingsih. 2016. The Effect Of Online Consumer Review Toward Purchase Intention: A Study In Premium Cosmetic In Indonesia. 
Journal International Conference On Ethics Of Business, Economics, And Social Science.

Thomas,Marc-Julian, Bernd W. Wirtz And Jan C. Weyerer (2019 )"Influencing Factors Of Online Reviews: An Empirical Analysis Of Determinants Of Purchase Intention” International Journal Of Electronic Business, Vol. 15, No. 1, 2019

Thompson Ronald, Christopher A And Howell Jane. (1991). Personal Computing : Toward A Conceptual Model Of Utilization. MIS Quarterly. March 1991

Tim Media Websindo. 2019. Indonesia Digital 2019 : Media Sosial. Https://Websindo.Com/Indonesia-Digital-2019-Media-Sosial, diakses 5 Januari 2020

Venkatesh, V. And Davis Fred D.2000. A Theoritical Extension Of The Thechnology Acceptance Model: Four Longitudinal Field Studies. Management Sciences. Vol. 46/2. Februari: 186-204.

Wang, R.Y. And Strong, D.M. (1996) 'Beyond Accuracy: What Data Quality Means To Data Consumers', Journal Of Management Information Systems, Vol. 12, No. 4, Pp.5-33.

Winoto , Y .2015. The Application Of Source Credibility Theory In Studies Aboutlibrary Services Penerapan Teori Kredibilitas Sumber (Source Of Credibity) Dalam Penelitian-Penelitian Layanan Perpustakaan. Journal Of Libabry And Information Science. Tahun 5, Volume 5 No. 2 Nopember 2015. 